\title{
Uma outra Nuvem de Calças: a retradução em busca de Maiakóvski
}

Letícia Mei ${ }^{1}$

Resumo: 0 artigo propõe uma retradução da primeira parte do longo poema de Maiakóvski "Nuvem de Calças" (1915), cuja primeira e, durante muito tempo, única tradução em português é assinada por E. Carrera Guerra. À luz de elementos característicos da poética maiakouskiana e de discussões teóricas acerca do espaço da retradução, este trabalho oferece e comenta brevemente novas soluções, apontando diferenças de perspectiva em relação à primeira obra. Palavras-chave: Maiakóvski, Nuvem de Calças, tradução de poesia, Emílio Carrera Guerra, retradução crítica.

\section{Introdução}

Maiakóvski é, provavelmente, o poeta russo mais conhecido no Brasil. Sua recepção deu-se, sobretudo, através das traduções realizadas por Augusto e Haroldo de Campos, em parceria com Boris Schnaiderman, presentes nas antologias Poesia Russa Moderna e Maiakóvski. Poemas. Outra compilação relevante foi Maiacovski. Antologia Poética, organizada e traduzida por Emílio Carrera Guerra, de 1956. Como fonte de todos, é impossível não mencionar a escritora argentina Lila Guerrero e sua Antologia de Maiacovski na difusão do poeta na América Latina. Há indícios de que tais tradutores também se serviram de traduções francesas, o que torna muito interessante coadunar o trabalho de pesquisa da tradução/recepção no Brasil, América Latina e França. ${ }^{2}$

1 Mestre e doutoranda em Literatura e Cultura Russa pela Faculdade de Filosofia, Letras e Ciências Humanas da Universidade de São Paulo.

2 Sobre o assunto escrevi o artigo Um russo em Montparnasse: percep̧ões de Maiakóvski na imprensa francesa (1921-1930) ainda inédito. 
A produção de Maiakóvski é colossal como ele. Sem considerar seu talento multifacetado em inúmeras outras áreas artísticas (cinema, artes dramáticas, desenho, pintura, etc.) percebe-se que ainda há uma grande lacuna nas traduções existentes em português. Em termos quantitativos, se examinarmos o total de poemas que compôs, curtos e longos, muito ainda há a se traduzir para o português; e também em termos de gênero, pois a maior parte do que dele se traduziu é classificado como "poema curto" ou "стихu (stikhi)", gênero poético diverso do "poema longo" ou "поэмa (доета)". É interessante na seleção de poemas de E. C. Guerra a atenção dedicada a esses últimos. De acordo com Frioux, tradutor da obra de Maiakóvski, é nesse gênero que se encontram mais bem trabalhados os temas ideológicos fundamentais da sua obra.

Concentrando-se nas obras basilares citadas, chega-se ao seguinte corpus: os irmãos Campos e o professor Boris traduziram fragmentos de $A$ Flauta-Vértebra, Sobre Isto e a Plenos Pulmões; Guerra traduziu trechos de $A$ Nuvem de Calças e integralmente $A$ Flauta Vertebrada, Amo e a Plena Voz. Em pesquisas mais recentes, descobri as traduções integrais de André Nogueira de Uma Nuvem de Calças e Amo que não discutirei neste artigo. Dentre tais obras, decidi abordar Nuvem de Calças, espécie de poema inaugural que consagrou Maiakóvski como um grande poeta no meio literário russo.

O intuito deste artigo é, pois, apresentar parte da tradução poética que desenvolvi no doutorado do poema Nuvem de Calças, comentar algumas diretrizes tradutórias e tecer reflexões críticas a respeito de algumas soluções propostas por Guerra $^{3}$. Para tanto, recorrerei a algumas discussões sobre (re)tradução crítica, bem como sobre a tradução poética já levantadas por Álvaro Faleiros, José Paulo Paes, Antoine Berman, Yves Gambier, dentre outros.

Na primeira parte, apresento o poema e o poeta, tentando contextualizar a posição dessa obra no conjunto e justificar sua escolha. Ainda, pretendo apontar as peculiaridades da fatura poética de Maiakóvski, uma vez que seus preceitos de como fazer versos sempre me norteiam na desafiadora tarefa de dar-lhe voz em português. Em seguida, apresentarei uma proposta de tradução poética para a primeira parte do poema. Por fim, abordarei algumas discussões teóricas sobre (re)tradução, crítica da tradução e tradução poética que têm embasado minha pesquisa; comentarei algumas soluções e discutirei algumas divergências em relação à tradução de Guerra.

3 Dada a extensão da primeira parte do poema, apontaremos apenas exemplos da tradução de Guerra e não transcreveremos seu trabalho na íntegra. 


\section{O poeta, sua poética, o poema}

\section{Como fazer versos ${ }^{4}$.}

A obra de Maiakóvski é múltipla, dinâmica, mas alinhavada por um todo coerente. Não se pode resumir a sua obra ao viés político, embora este seja parte integrante da sua poesia. Mesmo no mais lírico dos poemas, o encargo social e o projeto de um homem novo, articulado com novas dinâmicas sociais, sempre esteve presente. Lirismo e ideologia integrados. De todo modo, não se pode ignorar seus vínculos com o cubofuturismo, seu compromisso constantemente reiterado com as novas direções da arte e seu trabalho estético com a palavra. Qualquer desvio dessas considerações implica a redução de sua genialidade.

Independentemente do tema, o tratamento da palavra e o cuidado com o ritmo eram os princípios indispensáveis de sua oficina poética. Nessa empreitada, a sonoridade tinha um papel central, portanto Maiakóvski privilegiava as rimas inesperadas e a sonoridade áspera. Outras características da sua poética são a irregularidade da pontuação, a instabilidade dos aspectos verbais e a economia verbal.

$\mathrm{Na}$ minha proposta de tradução, é primordial a tentativa de recuperar a oralidade da sua linguagem. Para assegurá-la, procuro evitar o vocabulário rebuscado e não hesito em empregar palavras do cotidiano. Fujo, quando possível, das inversões sintáticas que conferem um tom pesado à tradução em português. No tocante ao metro, geralmente impera a polimetria, com grupos de diferentes metros agrupados ao longo dos poemas. No caso da presente tradução, tentei apenas respeitar a arquitetura geral do verso, longo ou curto.

Com efeito, os versos de Maiakóvski se destinam à voz, à recitação diante do público, constroem-se não sobre acentos métricos, mas sobre os acentos da língua falada. Um ponto importantíssimo da sua concepção sobre os versos é a questão do ritmo. Para ele há a repetição de um ruído primordial e o poeta deve esforçar-se para organizá-los, como postulava o formalista Óssip Brik em Ritmo e Sintaxe. Para o teórico, “o movimento rítmico é anterior ao verso" (BRIK, 1973, p. 132) e "no poeta, aparece antes a imagem indefinida de um complexo lírico dotado de estrutura fônica e rítmica e só depois essa estrutura transracional articula-se em palavras significantes." (BRIK, 1973, p. 137).

4 Alguns apontamentos desta sessão foram retomados da minha dissertação de mestrado "Sobre Isto": sintese da poética de Maiakóvski, defendida sob orientação de Arlete Cavaliere, em 2015. 
Maiakóvski era a favor da economia na arte, ou seja, suprimia o que parecia supérfluo, mantendo o essencial. O essencial para o seu encargo social. Embora os poemas narrativos como Nuvem de Calças não sejam concisos em sua extensão, pode-se falar, sim, em economia, na medida em que Maiakóvski faz largo uso das construções elípticas que dinamizam o verso, surpreendem e, muitas vezes, turvam a compreensão. Os estudos dos manuscritos empreendidos por Khardjiev e Trenin revelaram uma tendência essencial à expressividade lacônica. Não raro, Maiakóvski "remaneja as partes de um poema, rompe a unidade das construções sintáticas e acentua, assim, seu dinamismo" (KHARDJEV; TRENINE, 1982, p. 247). Nesta tradução tentei manter as mesmas construções e não desenvolver as elipses, uma prática, aliás, muito corrente nas traduções consultadas.

\section{Uma segunda tragédia}

Conforme apontado na introdução, para Frioux é justamente nos poemy, "grandes conjuntos de versos realizados em torno de um eixo semi-mitológico, semi-narrativo" (MAIAKÓVSKI, 2005, p. 8), que os fundamentos da obra maiakovskiana se constroem de modo mais bem-acabado. Segundo ele:

esses poemas balizam toda a criação de Maiakóvski. Pode-se mesmo dizer que eles lhe dão ritmo, formando uma série de articulações ou de pontos focais que incarnam, da maneira mais elaborada e mais completa, o conteúdo de todo o período de sua evolução. Os poemas [...] colocam em evidência a estrutura cíclica do procedimento maiakovskiano. Cada ciclo tem como material um certo número de elementos biográficos vividos, históricos, políticos que se projetam inicialmente sob uma forma imediata, mais frequentemente fragmentária ou dispersa [...]. Advém, em seguida, o segundo estágio, o poema propriamente dito, que extrai uma certa universalidade desse material e o estabelece como sistema associado às grandes linhas constantes do universo poético de Maiakóvski. (Tradução minha).

O gênero poema seria, então, uma transfiguração simbólica para enunciar temas fundamentais, ultrapassando o mero "grito lírico" e o "militantismo" banal.

Em Nuvem de Calcas, seu primeiro poema, Maiakóvski aborda o motivo do amor trágico. É um poema de amor, na medida em que foi inspirado por uma paixão que de fato viveu e porque a primeira parte visa desconstruir o amor in- 
feliz que lhe é infligido pelo mundo tal como ele era. Mas vai além: para mudar a configuração do amor doloroso, há que se mudar o mundo todo, o mundo do capital, da guerra e da superficialidade burguesa. Afinal, foi composto no início de 1915, mas seu projeto inicial data do ano anterior, momento de deflagração da Primeira Guerra Mundial. Em sua autobiografia Eu mesmo, o poeta diz: "Início de 1914. Sinto mestria. Posso dominar um tema. Inteiramente. Formulo a questão do tema. Um tema revolucionário. Penso em 'Uma nuvem de calças'.” (SCHNAIDERMAN, 1971, p. 95).

O título inicial da obra, $O$ décimo terceiro apóstolo, foi imediatamente vetado pela censura tzarista por blasfêmia. Além disso, outras seis páginas foram totalmente substituídas por reticências por tratarem de "temas politicamente sensíveis" (JANGFELDT, 2010, p. 77). O censor teria perguntado a Maiakóvski como associava tanto lirismo e rudeza. A resposta teria sido um trecho do prólogo do poema: "Se quiserem - / serei furioso até o osso / - e, como o céu, que novas cores realça / se quiserem - / serei perfeitamente afetuoso, / não um homem, mas uma nuvem de calças!"’5. Eis o título definitivo.

Em julho de 1915, em busca de um editor, Maiakóvski conhece Ossip e Lilia Brik, personagens centrais na sua obra e biografia a partir de então. Eles ouvem a primeira leitura da versão definitiva do poema. Óssip declara que Maiakóvski “é um grande poeta mesmo que nunca mais escreva uma linha sequer" (JANGFELDT, 2010, p. 77) e decide editá-lo às suas expensas. Entretanto, a primeira tiragem de 1050 exemplares não foi um sucesso de vendas.

Somente em 1918 Nuvem de Calças foi publicado integralmente, composto de quatro partes precedidas de um prólogo ${ }^{6}$ antecipando o tom provocatório da obra. O subtítulo "Tetráptico" faz uma referência ao típico tríptico do ícone ortodoxo.

5 Tradução minha.

6 Apresentei uma proposta de tradução do prólogo no artigo E por falar em poesia: especificidades tradutórias da lírica de Maiakóvski, publicado na revista Tradterm, v. 28 (2016). Tal proposta já foi revista e levemente modificada dentro da perspectiva de auto-retradução crítica. 


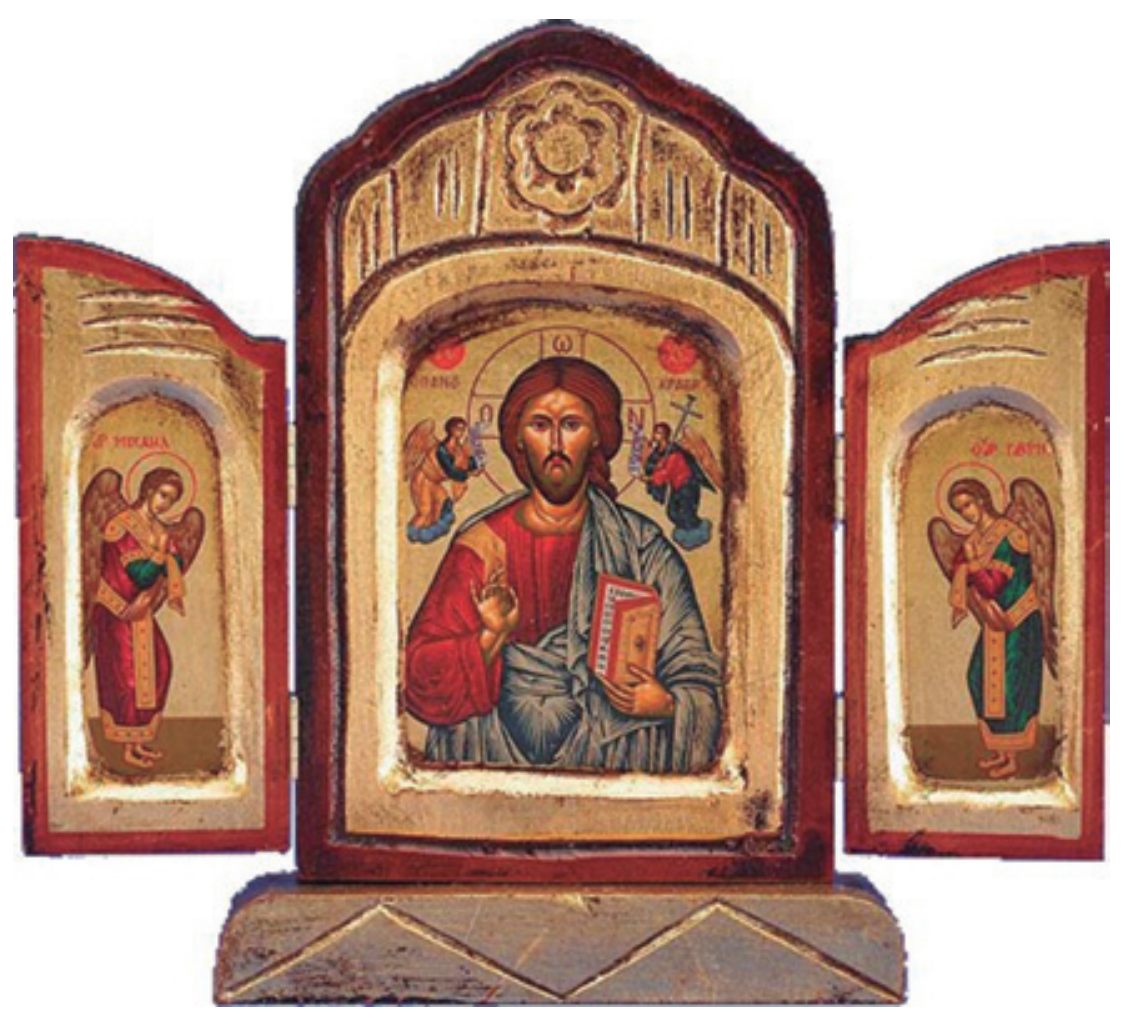

Figura 1. Tríptico de Cristo Pantocrator ${ }^{7}$

No prefácio dessa edição, Maiakóvski sentencia: "Eu considero Nuvem de Calças o catecismo da arte atual. 'Abaixo o seu amor', 'abaixo a sua arte', 'abaixo a sua ordem', 'abaixo a sua religião' são os quatro gritos das quatro partes”. (MAIAKÓVSKI, 2000, p. 69).

Segundo outro especialista na obra de Maiakóvski, Jangfeldt, por "seu” pode-se apreender "do mundo capitalista" (JANGFELDT, 2010, p. 71). No entanto, para ele não se trata de uma revolta social, embora o protesto não seja desprovido de tal dimensão. No final das contas, é uma "revolta mais profunda, uma revolta existencial contra uma época e uma ordem de mundo que faz da vida humana uma tragédia." Para Jangfeldt (2010, p. 75) é, em suma, uma revolta contra Deus:

7 http://www.archangelsbooks.com/prodimages/Giant/Icons/LUM136602906.jpg, acesso em 09 de setembro de 2017. 
o responsável pelo amor infeliz e impossível de Maiakovski não é ninguém além de Deus [...] O amor conduz o homem à loucura, à beira do suicídio, mas o céu permanece mudo; não há ninguém a quem pedir explicações. A ordem do mundo permanece imutável, a revolta é vã e encontra apenas o silêncio. (Tradução minha).

O diálogo mais imediato se estabelece com a peça Vladímir Maiakóvski. Uma Tragédia, de 1913. No ensaio "Sobre os vários Maiakóvski", o próprio poeta chama Nuvem de Calças de "sua segunda tragédia". Suas características são sui generis se observarmos a produção anterior e considerarmos que em 1914-15 o cubofuturismo estava no auge. Jangfeldt (2010, p. 70) diz que se comparada às obras anteriores,

a Nuvem era de um não-futurismo surpreendente. Com efeito, o poema continha metáforas audaciosas e neologismos, mas não consistia mais naquela poesia experimental de formalismo áspero que fizera sua reputação. Não, a novidade residia na mensagem e no tom, mais expressionista que futurista. (Tradução minha).

O poema completo tem 724 versos. Aqui, apresento uma proposta de retradução poética dos 178 versos da primeira parte do poema. Nela fala-se do amor por Maria, cuja inspiração muito provavelmente vem de Maria Denissova, jovem por quem Maiakóvski se apaixonara. Nesta sessão, o eu-lírico a espera em um quarto de hotel, mas a impaciência faz com que um nervo salte do crânio. Em seguida, outros nervos saltam em violenta convulsão que faz desabar o forro do teto do andar de baixo. Finalmente Maria chega e, fria, anuncia seu casamento. O eu-lírico aparenta calma, mas no fundo há um "eu" violento que quer se rebelar e fugir de si. Ele está doente, em chamas, mas não se pode escapar do incêndio do próprio coração.

Aí se prenunciam muitos traços das obras subsequentes. Com forte carga emocional e metáforas surpreendentes, Nuvem de Calças constitui uma obra basilar concentrando temas que irrigam toda a sua obra: loucura, suicídio, conflito com Deus, miséria existencial. Que o primeiro painel do tetrático consiga sugerir ao leitor a relevância da obra inteira. 


\section{Uma possibilidade de retradução}

ОБААКО В ШТАНАХ

I

Вы думаете, это бредит малярия?

Это было,

было в OАecce.

“Прилу в четыре", - сказала Мария.

Восемь.

Аевять.

Аесять.

Вот и вечер

в ночную жуть

10 ушел от окон,

хмурый,

Аекабрый.

В Аряхлую спину хохочут и ржут

канделябры.

Меня сейчас узнать не могли бы:

жилистая громадина

стонет,

корчится.

Что может хотеться этакой гАыбе?

20 А глыбе многое хочется!

Ведь Аля себя не важно

и то, что бронзовый,

и то, что серАце - холодной железкою.

Ночью хочется звон свой

спрятать в мягкое,

в женское.

И вот,

громадный,

\section{NUVEM DE CALÇAS}

\section{I}

Acham que é delírio da malária?

Aconteceu, aconteceu em Odessa.

"Virei às quatro" - disse Maria.

Oito.

Nove.

Dez.

A tarde tomba

sombria,

fria,

escapa pela janela

rumo ao noturno macabro.

Às costas decrépitas, ri e rincha

o candelabro.

Ninguém poderia me reconhecer:

o colosso fibroso

geme

e se debate.

O que tal bloco pode querer?

Esse bloco tem tantas vontades!

Afinal não importa

se é de bronze

e o coração de ferro frio

À noite, quer abafar

seu som na suavidade,

no feminino.

Aqui estou, colossal, 
горблюсь в окне,

30 плавлю Абом стекло окошечное.

Будет Аюбовь или нет?

Какая -

большая или крошечная?

Откуда большая у тела такого:

АОАжно быть, маленький,

смирный Аюбёночек.

Она шарахается автомобильных гудков.

Аюбит звоночки коночек.

Еще и еще,

40 уткнувшись АОЖАЮ

Аицом, в его Аицо рябое,

жАу,

обрызганный громом городского прибоя. salpicado pelo trovão da ressaca da cidade.

Полночь, с ножом мечась,

догнала,

зарезала, -

вон его!

Упац Авенадцатый час,

как с плахи голова казненного.

50 В стеклах АожАинки серые

свылись,

гримасу громадили,

как будто воют химеры

Собора Парижской Богоматери.

Проклятая!

Что же, и этого не хватит?

Скоро криком издерется рот.

Слышу:

тихо,

60 как больной с кровати, спрыгнул нерв.

И вот, -

сначала прошелся curvo-me para a janela,

fundo a fronte na vidraça.

Será amor ou não?

De que tipo -

grande ou minúsculo?

Como pode ser grande num corpo assim?

Deve ser um amor

pequeno e sereno.

Ele sobressalta com a buzina dos carros.

Gosta da campainha dos bondes a cavalo.

Mais e mais,

mergulhando o rosto

no rosto bexigoso da chuva,

espero,

Vem a meia-noite, sacudindo a faca,

capturou,

decapitou, -

Fora!

Caiu a décima segunda hora,

como do cadafalso a cabeça de um condenado.

Nas vidraças, gotas de chuva gris

contorciam-se sibilando

compondo caretas,

como se latissem as quimeras

da Notre-Dame de Paris.

Maldita!

Então ainda não basta?

Em breve o grito rebenta a boca.

Ouço:

silenciosamente

saltou um nervo,

como da cama um doente.

Veja, -

primeiro veio 
еАва-еАва,

потом забегац,

взволнованный,

четкий.

Теперь и он и новые Ава

мечутся отчаянной чечеткой.

70 Рухнула штукатурка в нижнем этаже.

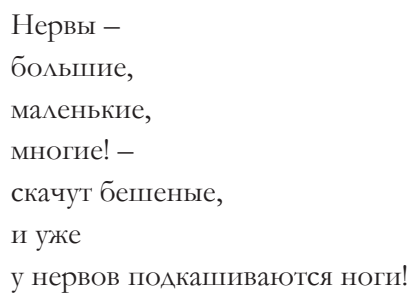

devagar,

depois se pôs a correr,

inquieto,

preciso.

Agora, ele e mais dois

chacoalham num sapateado desesperado.

Desabou a argamassa do andar de baixo.

А ночь по комнате тинится и тинится, - E a noite enlameia mais e mais o quarto, из тины не вытянуться отяжелевшему глазу. do lodo o olho pesado não se desvencilha.

80 Авери вАруг заляскали, буАто у гостиницы не попадает зуб на зуб.

Вошла ты, резкая, как “нате!”, муча перчатки замш, сказала;

"Знаете я выхожу замуж”.

Что ж, выходите,

90 Ничего.

Покреплюсь.

Видите - спокоен как!

Как пульс

покойника.

Помните?

Вы говорили:

"Ажек МонАон,
As portas começam a ranger de repente, como se todo o hotel batesse os dentes.

Entrou, cortante como um "é com você!", torturando as luvas de camurça, disparou:

"Vê...

Vou me casar".

Que seja, case-se.

Não faz mal.

Vou me conter.

Vejam - tão calmo!

Como o pulso

de um cadáver.

Lembra?

Você dizia:

"Jack London, ${ }^{8}$

8 Escritor norte-americano de grande sucesso mundial à época. 
Аеньги,

dinheiro,

Аюбовь,

amor,

100 страсть", -

paixão" -

а я оАно виАел:

E eu só via uma coisa:

вы - Ажиоконда,

você era a Gioconda

которую надо украсть!

И украли.

que eu tinha de roubar!

E roubaram.

Опять влюбленный выйАу в игры,

Apaixonado, entrarei no jogo de novo,

огнем озаряя бровей загиб.

Что же!

И в Аоме, который выгорел,

иногАа живут бездомные бродяги!

110 Аразните?

"Меньше, чем у нищего копеек, у вас изумрудов безумий”.

Помните!

iluminando o arco das sobrancelhas com fogo.

Tudo bem!

Nas casas incendiadas,

vivem às vezes vagabundos também!

Provocam-me?

"Tem menos esmeraldas de loucura, que o mendigo tostão"

Lembrem-se!

Погибла Помпея,

когда раздразнили Везувий!

Pompeia pereceu

por exasperar um vulcão!

Эй!

Ei!

Господа!

Senhores!

Аюбители

Amantes

святотатств,

de sacrilégios,

crimes,

carnificinas, -

боен, -

viram

а самое страшное

o mais terrível?

видели -

O meu rosto,

Аицо мое,

quando

я

аббсолютно спокоен?

estou

totalmente em paz.

И чувствую -

"я"

130 Аля меня мало.

Кто-то из меня вырывается упрямо.

Allo!

E sinto que

"eu"

para mim é pouco.

Alguém foge de mim como um louco.

Alô?

Кто говорит?

Quem fala?

Мама?

Mãe?

Мама!

Mãe! 
Ваш сын прекрасно болен!

Мама!

У него пожар сердца.

Скажите сестрам, Аюде и ОАе, -

140 ему уже некуда деться.

Каждое слово,

Ааже шутка,

которые изрыгает обгорающим ртом он,

выбрасывается, как голая проститутка

из горящего публичного Аома.

Аюди нюхают -

запахло жареным!

Нагнали каких-то.

Блестящие!

150 в касках!

Нельзя сапожища!

Скажите пожарным:

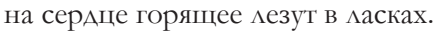

Я сам.

ГАаза наслезнённые бочками выкачу.

Аайте о ребра опереться.

Выскочу! Выскочу! Выскочу! Выскочу!

Рухнули.

Не выскочишь из сердца!

160 На Аице обгорающем

из трещины губ

обугленный поцелуишко броситься вырос.

Мама!

Петь не могу.

У церковки сердца занимается клирос!

Обгорелые фигурки слов и чисел

из черепа,

как дети из горящего зАания.

Так страх

170 схватиться за небо
Teu filho está magnificamente doente!

Mãe!

Ele tem um incêndio no coração.

Diz às irmãs, Liúda e Ólia, -

que ele já não tem pra onde fugir.

Cada palavra, até as piadas,

que sua boca queimada vomita, como uma prostituta nua se precipita do bordel que arde.

As pessoas farejam -

É de queimado esse cheiro!

Alguns correm.

Chegam capacetes brilhantes!

Com botas, não!

Digam aos bombeiros:

é com delicadeza

que se entra num coração.

Eu mesmo

bombearei barris dos olhos marejados.

Vou ficar de lado.

Vou pular! Vou pular! Vou pular! Vou pular!

Desabou.

Não dá para pular do próprio coração!

Sobre o rosto chamuscado, da fenda dos lábios,

um beijinho carbonizado tenta se lançar.

Mãe!

Não posso cantar.

$\mathrm{Na}$ capela do coração o coro se incendeia!

Silhuetas chamuscadas de palavras e números escapam do crânio, como crianças de uma casa em chamas.

Foi assim o terror

dos braços ardentes do Lusitânia ${ }^{9}$

9 Navio britânico bombardeado pelos alemães em 1915. 
высиА

горящие руки “Аузитании”.

Трясущимся АюАям

в квартирное тихо

стоглазое зарево рвется с пристани.

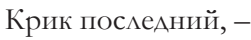

ты хоть

о том, что горю, в столетия выстони! erguendo-se

para agarrar o céu.

A tocha de mil olhos resvala no cais, invade a calma das camas de pessoas trêmulas.

Que ao menos meus gritos finais, gemam aos séculos que estou em chamas!

\section{Comentários sobre a (re)tradução}

\section{Apontamentos sobre o espaço da retradução}

Em sua tese de Livre-docência, Faleiros define a retradução como a "reapropriação de uma obra já traduzida, acrescentando-lhe novas leituras e relevos por meio da reescritura da reescritura; movimento duplo, voluntário ou não, de crítica: [...] A retradução configura-se, assim, como um espaço possível e rico de reflexão sobre o fazer poético.” (FALEIROS, 2010, p. 10). Para Gambier (1994, p. 413) "a retradução seria uma nova tradução, numa mesma língua de um texto já traduzido, parcial ou integralmente. Ela estaria ligada à noção de atualização dos textos, determinada pela evolução dos receptores, seus gostos, suas necessidades, suas competências".

Berman faz uma distinção entre tradução e retradução. Enquanto aquela pertence ao domínio do inacabado, a retradução circunscreve-se no espaço da busca pela completude. Consequentemente, as retraduções perfazem um caminho que virtualmente conduz à tradução perfeita num processo infinito de busca. Já para Skibinska (2007, p. 2) a retradução é o espaço em que se manifesta a subjetividade do tradutor e "um terreno de investigação de predileção para examinar os traços que o tradutor deixa no seu texto".

Terreno fértil, espaço múltiplo, a retradução pode ser vista como uma forma de crítica, "ao propor uma nova tradução em função de traduções já existentes." (FALEIROS, 2010, p. 29). Ainda sobre o viés crítico, de acordo com Paes, a crítica de tradução tem a função de determinar quanto há de perda, compensação ou até mesmo ganho durante o processo (PAES, 1990, p. 110).

A retradução constitui um fenômeno antigo e decorre de vários fatores, como decisões comerciais e editorais e necessidade de atualizar o texto traduzido. Já para Berman (1990, p. 5), a retradução surge da necessidade, não de suprimir, 
mas ao menos de reduzir, o esmaecimento do original. Particularmente, aprecio a visão de Susam-Sarajeva (SUSAM-SARAJEVA, 2003 apud SKIBINSKA, 2007, p. 5) segundo a qual "uma nova tradução não é necessariamente consequência do envelhecimento de uma ou mais traduções existentes ou da evolução dos gostos do público, tampouco se quer sempre superá-las”. Também concordo com Mavrodin (1990, p. 77), para quem muitas vezes a retradução se justifica pela compreensão diversa que se tem do texto traduzido, como um encenador que propõe um novo espetáculo.

Segundo Gambier (1994, p. 413), a retradução, levando em conta as versões precedentes, reelabora e encontra outras soluções para a tradução do texto de partida. Assim, a retradução conjuga as dimensões sócio-cultural e histórica. Compreendido o espaço próprio da retradução, a pergunta é: por que retraduzir? Gambier (1994, p. 415) responde: para preencher lacunas de textos parcialmente traduzidos, para corrigir possíveis contrassensos, para recuperar o estilo, o tom, o ritmo do original. No entanto, isso não significa que todas as retraduções forçosamente partam das primeiras versões, embora com elas se relacionem.

\section{Uma leitura do poema}

Conforme exposto anteriormente, meu "norte" na tradução de poesia são os traços da poética do escritor traduzido. Portanto, as características elencadas na sessão anterior balizam as soluções que busco alcançar. Conforme Tchukóvski, "o mais importante [é transmitir] a personalidade artística do autor traduzida em toda a originalidade do seu estilo." (TCHUKÓVSKI, 2003 apud Barreiros, 2005, p. 129). Assim, ilustrarei com exemplos os principais elementos que busquei recuperar: a sonoridade expressiva baseada nas rimas e aliterações marcantes, a manutenção das elipses e do caráter fragmentário do "fio narrativo" do poema, a oralidade da composição e o léxico acessível.

No que concerne à tradução de E. C. Guerra, de 1956, seu prefácio sugere seu objetivo e método. O intuito era "preencher uma lacuna" e repetir o que "em outros países cultos" haviam feito "pela divulgação do grande poeta russo". Segundo Guerra, os poemas da antologia eram quase todos inéditos em português e alguns mesmo em espanhol. Afirma ainda que para traduzir os poemas cotejou "versões francesas, espanholas e inglesas e, em questões de somenos", consultou "algumas vezes o texto russo". Prossegue: "em certos casos, tivemos que optar antes por uma adaptação do que por uma tradução propriamente dita" (MAIAKOVSKI, 1956, p. 4 ). 
A visão geral que se tem de sua tradução é que o conteúdo tem uma preponderância sobre a forma. Embora se tenham mantido a estrutura em versos e as imagens, pouca atenção foi dada a um dos aspectos fundamentais da poética de Maiakovski: a sonoridade. Parece-me que a proposta de Guerra está mais associada à ideia defendida por Goethe de uma tradução preocupada em expor o conteúdo, desvencilhando-se num primeiro momento dos recursos poéticos e apagando a estranheza do estrangeiro para melhor aclimatação da tradução em solo nacional.

Em Nuvem de Calcas, a complexidade da rima ainda está em desenvolvimento, percebe-se menos regularidade de ocorrências e menor complexidade de formação. Ainda assim, permanece um recurso fundamental na escrita do poeta russo.

Original:

Вот и вечер

в ночную жуть

ушел от окон,

хмурый,

мекабрый.

В Аряхлую спину хохочут и ржут канделябры.
Minba proposta:

A tarde tomba

sombria,

fria,

escapa pela janela

rumo ao noturno macabro.

Às costas decrépitas, ri e rincha o candelabro.
Tradução de Guerra:

E a tarde penetrou no horror da noite indo-se da janela para o frio de dezembro.

Às minhas costas, rindo, cintilavam os candelabros.

Nos versos 8 a 14, por exemplo, as rimas do original se fazem entre os termos: хмурый, декабрый, канделябры. A solução foi alterar a ordem dos versos e quebrar o grupo das rimas em "sombria-fria", enquanto "candelabro", no singular, ecoa "macabro" (Æymb, "horror"), o que não afeta a força da imagem. Para evitar o adjetivo "dezembrino" (декабръии), pouco usual no português quotidiano, optei por uma característica do inverno russo, daí o adjetivo "frio".

A dinâmica da tradução de Guerra tende à explicitação, não há tanta preocupação com a recuperação das marcas estilísticas do original. Talvez em função do filtro das línguas intermediárias. Nos versos acima, não se verificam rimas, aliterações e as imagens perdem a força. A imagem do original é grotesca: os candelabros animalizados gargalham e rincham com um sonoro "хохочут и ржут" em russo. Optei por "ri" e "rincha" para obter a aliteração e a onomatopeia do riso. O trecho selecionado exibe a metodologia que se estende por toda a tradução de Guerra.

Ainda acerca da sonoridade, como exemplo das escolhas das aliterações podem-se apontar: 
Minha proposta:

v. 8 "A tarde tomba"

v. 23 "ferro frio"

v. 51 "contorciam-se sibilando"

v. 57 "Em breve o grito rebenta a boca"

vv. 92-94 "tão calmo!/como o pulso/de um cadáver”

v. 155 "bombearei barris dos olhos marejados"
Soluções de Guerra:

"A tarde penetrou"

"metal gelado"

"se torciam/num ríctus"

"Em breve, um grito/vai destroçar-me a boca"

"Não vês como estou calmo/Dir-se-ia o pulso de um morto"

"Derramarei de meus olhos/tonéis de lágrimas"

Como a linguagem de Maiakóvski é fundamentalmente oral, privilegio soluções que contemplem a fluidez da declamação do poema. Um dos pontos de divergência com a tradução de Guerra refere-se à escolha do pronome de tratamento. Ele optou por "vós" e eu por "vocês". Em russo, o pronome empregado е́ вы que pode denotar tanto o singular de cortesia, quanto o plural formal ou informal. Minha intenção foi, conforme ideia de Schleirmacher, trazer o texto original de 1914-15 para o leitor de 2017 para que ele experimente o mesmo tom de proximidade que tinha o russo nativo àquela época. No meu projeto de tradução levei em conta o intuito de aproximar a voz de rua de Maiakovski da nossa variante atual de português. Acredito que "vós" envolve o texto em um véu que o afasta do leitor atual.

Como mencionado, Maiakóvski tinha uma linguagem fragmentada, elíptica. Procuro não cair na tentação de explicar ao leitor aquilo que era enigmático no original. Tal procedimento não se verifica na tradução de Guerra. Antes, há uma tendência à explicitação, ou seja, um desenvolvimento de elipses e um acréscimo frequente de explicações que não se observam no original. É compreensível que numa literatura fortemente vigiada o escritor desenvolva uma linguagem esópica. Portanto completar frases, organizar em demasia a sintaxe, explicar aquilo que mal foi sugerido não foram atitudes adotadas no meu processo tradutório.

Muitas outras observações poderiam ser feitas a respeito da minha tradução - que, aliás, é como toda tradução um trabalho em processo - e sobre a de Guerra. Apontei linhas gerais que indicam caminhos diversos na prática tradutória. A crítica não visa desvalorizar seu trabalho pioneiro, há inclusive boas soluções cuja inspiração absorvi, como nos seus versos "Eu para mim é pouco. Algo se empenha em sair de mim como um louco" ${ }^{10}$. Toda tradução envolve um sistema de perdas e ganhos (BERMAN, 1984, p. 20) e "a compensação é a estratégia básica da

10 Na minha tradução: E sinto que / "eu” / para mim é pouco. Alguém foge de mim como um louco. 
tradução de poesia" (PAES, 1990, p. 38). No jogo de aproximação e afastamento, textos de partida e de chegada devem caminhar lado a lado, sem subserviência de um em relação ao outro. Uma extensa rede dialógica envolvendo texto original, e (re)traduções. Como Berman, carrego a certeza de que não existe intraduzibilidade absoluta, assim como não há tradução perfeita. Ela é um processo contínuo e perene. Felizmente, pode-se sempre retraduzir. Nesse continuиm defendido por Gambier (1994), tradução é ato inacabado, um eterno refazer, interlocução constante em busca de uma perfeição inalcançável. Tela de Penélope tecida incessantemente à espera da tradução derradeira.

\section{Referências}

BARREIROS, José Colaço. "O Que é uma Boa Tradução?" "É uma Tradução Bem feita" "E o que é uma Tradução Bem Feita?...” Babilónia, Lisboa, n. 2-3, p. 129-145, 2005.

BERMAN, Antoine. «La retraduction comme espace de la traduction». Palimpsestes [en ligne], 4/1990. URL: http://palimpsestes.revues.org/596

1984.

. L'épreuve de l'étranger. Culture et traduction dans l'Allemagne romantique. Paris: Gallimard,

BRIK, Óssip. "Ritmo e Sintaxe". In: Teoria da literatura. Formalistas russos. Porto Alegre, Globo, 1973.

FALEIROS, Álvaro. Crítica e retradução poética. Tese apresentada ao Departamento de letras Modernas da Faculdade de Filosofia, Letras e Ciências Humanas da Universidade de São Paulo para obtenção do título de Livre-docente em Literatura Francesa. São Paulo, 2010. . Tradu₹ir o poema. São Paulo: Ateliê, 2012.

GAMBIER, Yves. «La retraduction, retour et détours». Meta 393 (1994): 413-417. DOI: 10.7202/002799ar.

JANGFELDT, Bengt. La vie en jeu. Paris: Albin Michel, 2010.

KHARDJIEV, Nikolai, TRENINE, Vladimir. La Culture Poétique de Maïakovski. Lausanne: L'Age d'Homme, 1982.

MAIAKOVSKI, Vladímir. Maiakovski. Antologia Poética. Trad. E. Carrera Guerra. Max Limonad, 1956. $\tan , 2000$.

. Poèmes. 1913-1917. Vol. 1. Trad. e apresentação de Claude Frioux. Paris: L'Harmat-

. À Pleine Voix. Anthologie Poétique 1915-1930. Prefácio de Claude Frioux. Trad. de Christian David, Paris: Gallimard, 2005.

MAVRODIN, Irina. Proust Traduit et retraduitSeptème Assises de a traduction litteraire (Arles 1990). arles: actes sud, 1991, p. 23-28. 
MEI, Letícia. E por falar em poesia: especificidades tradutórias da lírica de Maiakóvski, publicado na revista Tradterm, v. 28 (2016).

"Sobre Isto": sintese da poética de Maiakóvski. Dissertação de mestrado defendida na Universidade de São Paulo, junto ao Programa de Pós-Graduação em Literatura e Cultura Russa, sob a orientação de Arlete Cavaliere. São Paulo, 2015.

PAES, José Paulo. Tradução. A ponte necessária. Aspectos e problemas da arte de traduzir. São Paulo: Ática, 1990.

SCHNAIDERMAN, Boris. A Poética de Maiakóvski. São Paulo: Perspectiva, 1971.

SKIBINSKA, Elzbieta. La retraduction, manifestation de la subjectivité du traducteur. Doletiana $1,2007$.

TCHUKÓVSKI, Kornéi. La traduquione: una grande arte. Trad. Bianca Maria Balestra e Julia Dobrovolskaia. Veneza: Cafoscarina, 2003. 